\title{
A Water Quality Index Approach in Estimating Water Quality of Shallow Wells Situated Near Pollution Sources in a Community
}

\section{Olugbenga Elemile}

Landmark University

Enoch lbitogbe ( $\square$ ibitogbe.enoch@lmu.edu.ng )

Department of Civil Engineering, Landmark University, Omu-Aran, Kwara, Nigeria

https://orcid.org/0000-0003-3357-373X

\section{Olatunji Folorunso}

Ekiti State University Faculty of Engineering

\section{Praise Ejigboye}

Landmark University College of Science and Engineering

\section{Rotimi Adewumi}

Landmark University College of Science and Engineering

\section{Research}

Keywords: Assessment, Contamination, Shallow wells, Omu-Aran, Water quality index, $\mathrm{t}$ test

Posted Date: August 20th, 2020

DOl: https://doi.org/10.21203/rs.3.rs-54049/v1

License: (c) (i) This work is licensed under a Creative Commons Attribution 4.0 International License.

Read Full License 


\title{
A Water Quality Index Approach in Estimating Water Quality of Shallow Wells Situated Near Pollution Sources in a Community
}

\author{
${ }^{1}$ Elemile, O. O., ${ }^{1}$ Ibitogbe E. M., ${ }^{2}$ Folorunso, O. P., ${ }^{1}$ Ejiboye P.O and ${ }^{3}$ Adewumi J. R. \\ 1, Department of Civil Engineering, Landmark University, Omu-Aran, Kwara, Nigeria \\ 2 Department of Civil Engineering, Ekiti State University, Ado-Ekiti, Ekiti, Nigeria. \\ 3 Department of Civil Engineering, Federal University of Technology Akure, Nigeria. \\ Corresponding E-mail: ibitogbe.enoch@lmu.edu.ng
}

\begin{abstract}
:
BACKGROUND: Most developing countries rely on water sources that are usually not protected making them unsafe for drinking. These sources require regular assessment to evaluate their quality and ensure they meet standards before use. This research therefore assessed the physio-chemical and microbiological properties of selected shallow wells situated near pollution sources in Omu-Aran with an inclusive water quality index (WQI) framework. METHODS: Fifty groundwater samples were collected from five various locations namely: Aperan, Egbe garage, Latinwo, Mode and Igangu. Standard methods were used to determine the constituents of the water while descriptive statistics and two sample $t$ test were used to analyze the data.

RESULT: The mean values for turbidity, conductivity, total dissolved solids, total hardness, chloride and fluoride all fall within the nigerian Standard Drinking Water Quality guideline values while $\mathrm{pH}$, nitrite, dissolved oxygen and T. coliform exceed the standard limit. Coliform and nitrite contamination are often linked with sewage pollution arising from anthropogenic sources. The parameters of water in Omu-Aran were generally higher during the rainy season than the dry season. However, there was no significant difference for these parameters across periods except for $\mathrm{pH}$, Total hardness and fluoride. WQI classified water samples as Excellent, Good, Poor and Unsuitable for drinking.

CONCLUSION: Users should be encouraged to carry out disinfection and ensure their water sources are protected and not left exposed. The WQI makes it easy for policy makers to evaluate contamination and make decisions based on recommendation
\end{abstract}

KEYWORDS: Assessment; Contamination; Shallow wells; Omu-Aran; Water quality index; $t$ test.

\section{BACKGROUND}

Fresh water such as groundwater is distributed in many parts of the world and is usually abstracted for domestic, industrial and agricultural uses. Groundwater is always thought to be a safe source of drinking water as a result of low microbial load with little need for treatment before use [1]. This has proven not to be the case especially in developing countries where poor waste management may degrade their quality [2]. Anthropogenic activities have been found to influence groundwater 
quality [3] and majority of the microbial contaminants come from fecal sources of animals and humans [4]. Pathogenic microorganisms should not be found in water resources as disease outbreaks, including cholera and dysentery, are often the result of such contamination, according to the World Health Organization (WHO). Therefore, providing safe potable water, adequate sanitation and hygiene, are essential in protecting health, and directly contribute to achieving good health and well-being [5]. According to [6], the transmission of diseases such as acute watery diarrhea can be mitigated if potable water is made accessible. Research often shows impaired access can lead to health risk [7]. Water quality which is a major challenge for developing countries, including Nigeria, is usually the result of unequal access to potable water supply. Nigeria has only $19 \%$ of its population with access to safe drinking water and $67 \%$ of people have basic water supply [8]. This has forced many communities to adopt the current trend of abstraction of groundwater via boreholes and hand dug wells especially in rural areas. This is often the result when there is an inability to match the ever-increasing demand for water by government and its agencies [1]. Many of these sources are not regulated as they are done by private individuals while appropriate steps ensuring safe and sustainable water supply are often ignored. These water sources become easily polluted from waste arising from human activities, infiltrating sewage effluent and wash-down of contaminated soil surfaces $[9,10]$. The soil media can also play a major role in polluting groundwater. This is because soils can be laden with toxic metals and harmful organic substances which eventually find their way into water streams via infiltration [10]. In studies regarding water quality, surface waters and boreholes (deep wells) have received majority of the attention [11] whereas there is limited information on the status of shallow wells, but shallow wells are among the most important water sources in many sub-Saharan African rural areas $[12,13]$. The findings from this study provides useful information which could improve the use of shallow wells in order to solve water quality problems faced by the community. Apart from making information available, it is also necessary to provide it in a manner that makes it suitable for use and easy to interpret. One method often employed is the water quality index (WQI). According to [14], this is an effective tool that transforms large data quantities into distinct numbers making it comprehensive for consumers, stakeholders and policy makers to take decisions. WAWQI has been adopted by various researchers in different countries; Shimoga, India [15], Shatt Al- Kufa, Iraq [16], Vea dam, Bongo District, Ghana [17], AdoEkiti, Nigeria [18] and was used in this study. This research is aimed at examining water quality in shallow hand wells excavated in Omu-Aran and to investigate its suitability for domestic use by observing the physical, chemical and biological quality of the shallow well water in dry and wet seasons during 2019 - 2020.

\section{MATERIALS AND METHODS}

\section{Description of the study area and context}

The study area, Omu-Aran, is the Administrative Headquarters of Irepodun Local Government area of Kwara State, in the Northcentral axis of Nigeria. Omu-Aran is situated on latitude $8^{\circ} 08^{\prime} 00^{\prime \prime} \mathrm{N}$ and longitude $5^{\circ} 06^{\prime} 00^{\prime \prime} \mathrm{E}$ with an average elevation of $564 \mathrm{~m}$ above sea level as illustrated in Figure 1 . The climatic condition of the study area alternates between wet and dry which is known as rainy and harmattan respectively. The wet season usually last for seven months (April to October) with about 1100-1500 mm of rainfall while the dry season starts November and ends March. Omu-Aran falls within the Southern limit of the tropical Savanah zone of Nigeria which allows for a variety of vegetation outcrop [19].

\section{Collection of Samples}

A total of five sampling sites were selected which comprise hand dug wells at Aperan, Egbe garage, Mode, Latinwo and Igangu. These wells were assessed twice each month for a five-month period 
from September to January to account for both wet and dry season. A total of 50 samples were obtained across the study area using pre-sterilized screw capped bottles $(500 \mathrm{ml})$ in collecting water samples for microbial and physicochemical analysis which were kept in an ice filled cooler prior to analysis. The sampling locations were recorded using portable GPS device as displayed in Fig. 1.

Laboratory Analysis

Water samples were evaluated for their physicochemical quality according to the American Public Health Association (APHA) Standard Methods [20]. Onsite testing for parameters such as $\mathrm{pH}$, Dissolved Oxygen and Turbidity using mobile field kits was done immediately after sampling since they were sensitive and subject to change. Electrical conductivity (EC), Total Dissolved Solids (TDS), Total Hardness (TH), Chloride, Fluoride as well as Nitrite were analyzed in the laboratory using standard methods [20]. Microbiological examination of the water samples was done by plate count method using Mac-Conkey agar as the growth medium incubated for $24 \pm 1$ hrs at $37^{\circ} \mathrm{C}$ according to the standard methods [21]. The result of the analysis was reported as coliform forming unit (cfu/mL).

\section{Data Analysis}

Data for physio-chemical and microbial parameters were recorded for each location. Analysis of results were carried out using descriptive statistics and presented as mean and standard deviations and compared to Nigerian Standard Drinking Water Quality. The two sample $t$ test was used show if any significant difference exists for the measured parameters across the locations due to seasonal variation. Level of significance was taken as $(\alpha=0.05)$.

\section{Development of Water Quality Index}

Water Quality Index (WQI) shows the composite impact of various water quality parameters. It tries to give a single value which represents the entire constituents measured. All ten parameters were considered for developing the WQI. The Weighted Average Water Quality Index (WAWQI) first proposed by [22] was used to describe the quality of water obtained from hand dug wells and hence its suitability for use. The computation is given in four steps as described below:

Step 1: Proportionality constant " $\mathrm{K}$ " is estimated from the inverse of the standardized maximum concentration (Si). The value of $k$ depends on the amount of parameters involved in the study [23]. This is shown in Eqn. 1

$\mathrm{K}=\frac{1}{\sum_{i=1}^{n} \frac{1}{\mathrm{Si}}}$

Where, $\mathrm{K}$ is the constant of proportionality, $\mathrm{n}$, is the number of computed variables and $\mathrm{Si}$, is the standardized maximum concentration usually given by local authorities and international organizations.

Step 2: The relative weight (Wi) was then computed by using the following equation

$$
W_{i}=K / S_{i}
$$

Step 3: The quality rating is obtained by diving measured parameters with standard concentration given by NSDWQ guideline. It is shown in Eqn. 3

$$
Q i=100 *\left[\frac{V n-V i o}{S i-V i o}\right]
$$


Where; $Q i$ is sub-quality index rating. $V_{n}$ and $V_{i o}$ is the measured value and the ideal value of ith parameter respectively. ( $\mathrm{V}_{\text {io }}$ for $\mathrm{DO}$ is $14.6 \mathrm{mg} / \mathrm{L}$, and 7.0 for $\mathrm{pH}$ ).

Step 4: Finally, the water quality index, WQI was computed using this mathematical expression given in Eqn. 4

$W Q I=\sum W i Q i / \sum W i$

The water quality of different sites has been rated according to the WQI as given (Table 1).

\section{RESULTS AND DISCUSSION}

The results of the physicochemical analysis and microbial are presented in (Table 2).

\section{Turbidity}

Turbidity is a measure of the amount of light scattered and indirectly, the level of suspended particle in water. Usually particulate matter such as plankton, silt or clay could affect the appearance of water by obstruction of light. The mean turbidity values for each location as compared to NSDWQ values are displayed in Figure 2. There are relatively higher levels during rainy season $(0.96 \pm 0.30)$ NTU as compared to the dry $(0.82 \pm 0.22)$ NTU. However, there was no significant difference for the two periods as shown in Table 3 (alpha level of 0.05 ). The relatively higher turbidity levels during the rainy season is a result of runoff and percolation of water into receiving wells. These wells are not properly lined and as such are left exposed to sediments from runoff during this season. High turbidity values, apart from making the water undesirable due to aesthetic concerns could affect effective disinfection $[24,25]$. Turbidity could also indicate the presence of microbial contamination $[26,27]$. This is usually the product of the rather adsorptive characteristics of colloids as well as their ability to shield microorganisms from disinfection [11].

\section{$p H$}

$\mathrm{pH}$ is important in assessing water quality and seen as a significant parameter [11]. Therefore, although it does not have a direct impact on human health, it is necessary for adequate water quality analysis to be carried out. The mean values of $\mathrm{pH}$ for each location as compared to NSDWQ values fall below acceptable limits as displayed in Figure 3. Significant differences were observed in $\mathrm{pH}$ values (Table 3) for dry $(6.02 \pm 0.16)$ and wet conditions $(6.19 \pm 0.138)$ and could be a result of increased cations from chemical compounds and effluents. The differences in $\mathrm{pH}$ values across sampling points all fall below acceptable limits. Water becomes corrosive at low $\mathrm{pH}$ values which gives organoleptic concerns, [28]. Generally, lower $\mathrm{pH}$ levels tend to increase the corrosion level. Water that is acidic in nature causes rust in construction materials used for well services such as casings and screens while household utensils are also not left out.

\section{Electrical Conductivity}

The presence of dissolved ions in water affects conductivity. The importance of EC is its salinity measure which usually affects the taste and therefore the acceptance of water by the user. The mean EC values for each location as compared to NSDWQ values are displayed in Figure 4. They all fall within the maximum guideline requirement of $1000 \mu \mathrm{S} / \mathrm{cm}$ with the exception of Igangu that exceeds this value for rainy season. This is probably because the well is often exposed to the weather elements since it is usually left open. Analysis reveal that there was no significant difference between EC values for both rainy and dry periods as shown in Table 3 (alpha level of 0.05) although there were relatively higher EC levels during rainy season $(491.3 \pm 466.39) \mu \mathrm{S} / \mathrm{cm}$ as compared to 
the dry (347.07 \pm 308.59$) \mu \mathrm{S} / \mathrm{cm}$. The water is fresh water in nature since it does not exceed 1500 $\mu \mathrm{s} / \mathrm{cm}$ which is a standard value for freshwater according to [29].

\section{Total Dissolved Solids}

TDS concentration represents inorganic salts and small quantities of organic compounds [30]. It is one of the attributes that determines the quality of drinking water. The mean values of TDS for each location as compared to NSDWQ values are well within acceptable limits with the exception of Igangu (Figure 5). The maximum guideline requirement of $500 \mathrm{mg} / \mathrm{L}$ was exceeded in Igangu during the rainy season. There was no observable significant difference between TDS values for both rainy and dry periods as shown in Table 3 (alpha level of 0.05) although there were relatively higher TDS levels during rainy season $(253.73 \pm 245.70) \mathrm{mg} / \mathrm{L}$ as compared to the dry $(170.02 \pm 149.68) \mathrm{mg} / \mathrm{L}$. Water is often polluted with high TDS levels when untreated wastewater is disposed of into pits and surface waters that ultimately flow down to the water table [31]. Water could become corrosive destroying storage containers and unfit to drink [3].

\section{Total Hardness}

Total hardness is important when considering water for domestic purposes. There have been reports that it plays a role in the formation of kidney stones and cause cardiac problems. [32]. The mean turbidity values for each location as compared to NSDWQ values are displayed in Figure 6. The values of TH ranged from 31.48 to $136.67 \mathrm{mg} / \mathrm{l}$ and all values were within the limits allowed by the NSDWQ at $150 \mathrm{mg} / \mathrm{L}$. Results show relatively higher levels exist during rainy season (99.86 \pm 48.72) $\mathrm{mg} / \mathrm{L}$ as compared to the dry $(61.62 \pm 52.32) \mathrm{mg} / \mathrm{L}$. Significant differences exist across the varying rainy and dry periods as shown in Table 3 (alpha level of 0.05). Hardness in essence a combination of both calcium and magnesium ions. Hence, it is possible that rainfall would eventually bring an increase in water hardness due to dissolution of calcium and magnesium containing minerals.

\section{Nitrite}

The long-term effect arising from elevated nitrate and nitrite levels (usually due to intense agricultural practices and use of nitrogen-based chemicals) on the quality of ground water is global [33]. It is therefore paramount in understanding the quality of water systems. The mean nitrite values displayed in Figure 7 for each location do not meet the guideline values of $0.02 \mathrm{mg} / \mathrm{L}$ which is the maximum requirement set by the NSDWQ. The well at Igangu was observed to have extremely high values of $1.35 \mathrm{mg} / \mathrm{L}$ compared to other locations. This could be due to poor maintenance and constant exposure (no lid) making it susceptibile to contamination. There are relatively higher levels during the rainy season $(0.31 \pm 0.54)$ as compared to the dry $(0.06 \pm 0.16) \mathrm{mg} / \mathrm{L}$. However, the nitrite values did not vary significantly for both wet and dry seasons as seen in Table 3 (alpha level of 0.05 ). This result agrees with similar study carried out by [34]. It has been reported that occurrence of elevated nitrite concentration is mostly common in shallow dug wells immediately after heavy precipitation. Also, the presence of nitrites and nitrates in groundwater may also be a sign of sewage pollution derived from the effluent discharged from seepage beds [35]. Increase in nitrate and nitrate levels above the permissible level can lead to health problems like methemoglobinemia especially in children [36]. Therefore, it is of necessity to make only potable water which has been treated available for drinking especially to infants [36]. Alternative potable groundwater sources should be utilized especially boreholes which can be treated before consumption. 


\section{Chloride}

Chloride values ranged from $10.34 \pm 9.17$ to $40.85 \pm 8.89 \mathrm{mg} / \mathrm{L}$. The values were observed to be significantly different. The well at Mode was found to be the highest $(40.85 \pm 8.89 \mathrm{mg} / \mathrm{L})$ although it was still below the permissible guideline value (WHO) which is $250 \mathrm{mg} / \mathrm{L}$. The values were akin to the values reported by [3] done in the same study area. There are relatively higher levels during the rainy season $(34.50 \pm 16.03)$ as compared to the dry $(18.95 \pm 16.20) \mathrm{mg} / \mathrm{L}$. Chloride does not vary temporally and differences are insignificantly both wet and dry seasons as illustrated in Table 3 (alpha level of 0.05). [37] suggested natural causes of chloride could be a result of rainfall as well as dissolution of chloride-bearing minerals whereas anthropogenic sources may be derived from extensive use of fertilizers, landfill leachates and via effluents of inappropriately constructed soakaway pits which increase chloride concentration. Moreover, it could be significant in detecting sewage contamination of groundwater $[3,38]$.

\section{Fluoride}

The fluoride values ranged between $0.28 \pm 0.18$ and $0.67 \pm 0.66 \mathrm{mg} / \mathrm{L}$. The values at Aperan gave the highest value of $0.67 \pm 0.66 \mathrm{mg} / \mathrm{L}$ while the lowest was recorded at Egbe garage and this could be a result of the varying aquifer conditions. While all values were below permissible values given by WHO and SON, on the other hand, they were above values $(0.17 \pm 0.22) \mathrm{mg} / \mathrm{L}$ reported by [28]. Fluoride occurs naturally as a result of weathered run-off from fluoride-containing rocks and leaching from soils into groundwater [38]. Exposure to high levels of fluoride can lead to mottling of teeth and, in severe cases, crippling skeletal fluorosis. Water containing high fluoride concentrations may be treated by mixing it with a water solution having a lower level of fluoride. This process is often known as blending and where this cannot be done, de-fluoridation becomes the desirable technique employed to prevent fluorosis [39].

\section{Dissolved Oxygen}

Dissolved oxygen have been used to evaluate water quality across different locations and in different water bodies [40]. DO values range from $5.96 \pm 0.21 \mathrm{mg} / \mathrm{L}$ to $6.24 \pm 0.20 \mathrm{mg} / \mathrm{L}$ while they were observed to be lower than recommended guideline values (i.e they fall below the standard values of $7.5 \mathrm{mg} / \mathrm{L}$ ) by NSDWQ as displayed in Figure 10. Lower DO values was recorded for Mode which is probably a result of presence of organic matter and micro-organisms as they tend to influence oxygen levels through metabolism. Figure 10 shows high coliform content contamination in Mode. There are relatively lower levels during the rainy season $(6.10 \pm 0.16)$ as compared to the dry $(6.11 \pm 0.24) \mathrm{mg} / \mathrm{L}$. However, this temporal variation was not significantly different as illustrated in Table 3 (alpha level of 0.05). Values are comparably higher than values from a previous study carried out by [3].

\section{Total Coliform count}

The presence of coliform bacteria in drinking water usually indicates risks of microbial contamination through human or animal excreta [41]; it is usually taken as a fecal contamination indicator [42]. The coliform count was seen to be higher during the months with peak rainy periods than the dry periods although it was not significantly different as shown in Table 3. The mean values of coliform count for each location as compared to NSDWQ values are displayed in Figure 11. Although, the WHO has specified a zero limit contamination for coliform, NSDWQ recommends 10 $\mathrm{cfu} / \mathrm{ml}$ as the guideline value and even this was exceeded in all locations except Aperan. The health of the public can be seriously affected by threat posed by bacteriological contamination in the form of a coliform organism. Coliforms can cause a variety of waterborne illnesses from diarrhea to typhoid and even infections of the urinary system. 


\section{Quality Indices}

The water quality index gives an overview of the quality status of a water source and can also show how temporal and spatial variations influence water quality. Another major use is its interpretability and ease of comprehension as discussed earlier. Therefore, the computed WAWQI fulfills this purpose. The results of the water quality index are shown in Table 4. Aperan and Egbe garage were classified as excellent and good for respective dry and wet seasons. Mode and Latinwo were classified as good in both temporal conditions although microbial contamination make this water unsuitable for drinking if no proper treatment (such as chlorination) is adopted. The major contributing parameters to the low water quality represented by the index were EC, Nitrite, and Coliform count especially at Igangu hence its poor state. It was observed also that water quality was relatively better during low rainfall periods as compared to higher rainfall periods (Figure 12). The resulting contamination of effluents coming from nearby dumps, poor drainages and compromised soak away pits could during peak rainfall periods could be a major cause, which was the situation at lgangu, Mode and Latinwo.

\section{CONCLUSION}

The parameters of water in Omu-Aran were generally higher during the rainy season than the dry season. However, there was no significant difference for these parameters across periods except for $\mathrm{pH}$ and Total hardness. The mean values for Turbidity, Electrical conductivity, Total dissolved solids, Total hardness, Chloride and Fluoride were within the Nigerian Standard Drinking Water Quality guideline values of $5 \mathrm{NTU}, 1000 \mu \mathrm{S} / \mathrm{cm}, 500 \mathrm{mg} / \mathrm{L}, 150 \mathrm{mg} / \mathrm{L}, 250 \mathrm{mg} / \mathrm{L}$ and $1.5 \mathrm{mg} / \mathrm{L}$ respectively. On the other hand, key parameters such as $\mathrm{pH}$, Nitrite, Dissolved oxygen and Coliform exceed standard limits for drinking wáter of $6.5 \mathrm{NTU}, 7.5 \mathrm{mg} / \mathrm{L}, 10 \mathrm{cfu} / \mathrm{mL}$ respectively. The T. Coliform and Nitrite contamination is suspected to be from anthropogenic source such as faulty sewage and septic tanks. The water quality index as computed gives relevant information showing selected locations as classified as Excellent, Good, Poor and Unsuitable for drinking. The major contributing parameters to the low water quality represented by the index were Nitrite, and Coliform count especially at Igangu hence its poor state. It is recommended that water be treated before consumption while special care should be given to ensure wells are protected from contamination.

\section{ABBREVIATIONS}

$\begin{array}{ll}P & \text { Level of significance } \\ \text { APHA } & \text { American public health association } \\ \text { Chloride } & \text { Chloride } \\ D O & \text { Dissolved oxygen } \\ E & \text { East } \\ \text { EC } & \text { Electrical Conductivity } \\ k & \text { Constant of proportionality } \\ L & \text { Liter } \\ m g & \text { Milligram } \\ M L R & \text { Multiple Linear Regression } \\ N S D W Q & \text { Nigerian drinking standard water quality } \\ N & \text { North } \\ N T U & \text { Nephleometric turbidity unit } \\ \text { pH } & \text { pH (Hydrogen potential) } \\ S i & \text { Standardized maximum concentration }\end{array}$




$\begin{array}{ll}\text { Std. dev } & \text { Standard deviation } \\ T . \text { coliform } & \text { Total coliform } \\ t \text { test } & \text { Gosset's student distribution } \\ T D S & \text { Total dissolved solids } \\ T H & \text { Total Hardness } \\ V_{i o} & \text { Ideal value of ith parameter } \\ V_{n} & \text { Measured value of the ith parameter } \\ W A W Q I & \text { Weighted average water quality index } \\ W H O & \text { World health organization } \\ W_{i} & \text { Relative weight } \\ W Q I & \text { Water quality index }\end{array}$

\section{Declarations}

\section{Ethics approval and Consent to participate}

Not applicable to this manuscript.

\section{Consent for Publication}

The authors have given their approval for the manuscript to be published by the manuscript.

\section{Availability of data and Materials}

The authors confirm that the data supporting the findings of this study are available within the article.

\section{Competing Interests}

The authors declare that there are no competing interest

\section{Funding}

The authors did not receive any funding from any source.

\section{Conflict of Interest}

The authors declare no potential conflict of interest regarding the publication of this work. In addition, the ethical issues including plagiarism, informed consent, misconduct, data fabrication and, or falsification, double publication and, or submission, and redundancy have been completely witnessed by the authors.

\section{Acknowledgements}

The authors are ever grateful for the support and collaborative effort they received from the community while carrying out this research and the Management of Landmark University for making available a platform for carrying out researches.

\section{Author Contributions}

All authors had full access to the data in the study and take responsibility for the integrity and accuracy of the data análisis. E. Ibitogbe wrote the manuscript. O. Elemile: provided materials, experimental design, formulated study aim and goals and graphical presentation. O. Folorunso: proof read the manuscript. R. Adewumi: data analysis. P. Ejigboye: laboratory analysis and collection of the water samples. All authors read and approved the final manuscript. 


\section{REFERENCES}

[1] Palamuleni, L., \& Akoth, M. (2015). Physico-chemical and microbial analysis of selected borehole water in Mahikeng, South Africa. International journal of environmental research and public health, 12(8), 8619-8630.

[2] Ferronato, N., \& Torretta, V. (2019). Waste mismanagement in developing countries: A review of global issues. International journal of environmental research and public health, 16(6), 1060.

[3] Elemile, O. O., Raphael, D. O., Omole, D. O., Oloruntoba, E. O., Ajayi, E. O., \& Ohwavborua, N. A. (2019). Assessment of the impact of abattoir effluent on the quality of groundwater in a residential area of Omu-Aran, Nigeria. Environmental Sciences Europe, 31(1), 16.

[4] Takal, J. K., \& Quaye-Ballard, J. A. (2018). Bacteriological contamination of groundwater in relation to septic tanks location in Ashanti Region, Ghana. Cogent Environmental Science, 4(1), 1556197.

[5] UN (2018), SDG 6 Synthesis Report 2018 on Water and Sanitation, UN, New York.

[6] Rajasingham, A., Harvey, B., Taye, Y., Kamwaga, S., Martinsen, A., Sirad, M., Aden, M., Gallagher K., \& Handzel, T. (2020). Improved chlorination and rapid water quality assessment in response to an outbreak of acute watery diarrhea in Somali Region, Ethiopia. Journal of Water, Sanitation and Hygiene for Development.

[7] Nayebare, J. G., Owor, M. M., Kulabako, R., Campos, L. C., Fottrell, E., \& Taylor, R. G. (2020). WASH conditions in a small town in Uganda: how safe are on-site facilities?. Journal of Water, Sanitation and Hygiene for Development, 10(1), 96-110.

[8] Odume, N., Slaughter, A., How Nigeria is wasting its rich water resources. The Conversation (2017). Last updated: 5 September 2017. Accessed: 15 January 2019. Retrieved from http://theconversation.com/how-nigeria-is-wasting-its-rich-water-resources-83110

[9] Saria, J. A., \& Thomas, I. M. (2012). Water quality in selected shallow wells in Dar es Salaam. Huria: Journal of the Open University of Tanzania, 11, 13-24.

[10] Elemile, O. O., Raphael, O. D., Omole, D. O., Oluwatuyi, O. E., Ajayi, E. O., Umukoro, O., \& Elemile, M. G. (2019, November). Assessment of the impact of abattoir activities on the physicochemical properties of soils within a residential area of Omu-Aran, Nigeria. In IOP Conference Series: Materials Science and Engineering (Vol. 640, No. 1, p. 012083). IOP Publishing.

[11] Mbaka, P. K., Mwangi, J. K., \& Kiptum, C. K. (2017). Assessment of water quality in selected shallow wells of Keiyo Highlands, Kenya. African Journal of Science, Technology, Innovation and Development, 9(3), 329-338.

[12] Foster, S., Tuinhof, A., \& Van Steenbergen, F. (2012). Managed groundwater development for water-supply security in Sub-Saharan Africa: investment priorities. Water SA, 38(3), 359-366.

[13] Gowing, J., Parkin, G., Forsythe, N., Walker, D., Haile, A. T., \& Alamirew, D. (2016). Shallow groundwater in sub-Saharan Africa: neglected opportunity for sustainable intensification of smallscale agriculture?. Hydrology and Earth System Sciences Discussions, 1-33 (33 pages). 
[14] Saleem, M., Hussain, A., \& Mahmood, G. (2016). Analysis of groundwater quality using water quality index: A case study of greater Noida (Region), Uttar Pradesh (UP), India. Cogent Engineering, 3(1), 1237927.

[15] Yogendra, K., \& Puttaiah, E. T. (2008). Determination of water quality index and suitability of an urban waterbody in Shimoga Town, Karnataka. In Proceedings of Taal2007: The 12th world lake conference (Vol. 342, p. 346)

[16] Kizar, F. M. (2018). A comparison between weighted arithmetic and Canadian methods for a drinking water quality index at selected locations in shatt al-kufa. MS\&E, 433(1), 012026.

[17] Boah, D. K., Twum, S. B., \& Pelig-Ba, K. B. (2015). Mathematical computation of water quality index of Vea dam in upper East region of Ghana. Environmental Sciences, 3(1), 11-16.

[18] Oni, O., \& Fasakin, O. (2016). The use of water quality index method to determine the potability of surface water and groundwater in the vicinity of a municipal solid waste dumpsite in Nigeria. American Journal of Engineering Research (AJER), 5(10), 96-101.

[19] Iheme, K. O., Usman, A., Obaro, R. I., Aganigbo, C. I., \& Gbadebo, A. F. (2018). Hydro-Geophysical Assessment of Groundwater Resources Within Parts of Omu Aran, South Western Nigeria. Journal of Research Information in Civil Engineering, 15(4).

[20] Apha, A. (2005). Wef. Standard methods for the examination of water and wastewater, 21, 572.

[21] Apha, A. W. W. A. (2012). WEF.(2012). Standard methods for the examination of water and wastewater, 22.

[22] R.K. Horton An index number system for rating water quality, J. Walter Poll. Cont. Fed., 37 (3) (1965), pp. 300-306

[23] Aliyu, G. A., Jamil, N. R. B., Adam, M. B., \& Zulkeflee, Z. (2019). Assessment of Guinea Savanna River system to evaluate water quality and water monitoring networks. Global Journal of Environ. Sci. and Mgt., 5(3), 345-356.

[24] Patil, V. T., \& Patil, P. R. (2011). Groundwater quality of open wells and tube wells around Amalner town of Jalgaon district, Maharashtra, India. Journal of Chemistry, 8(1), 53-58. (7 pages).

[25] World Health Organization. (2006). The world health report 2006: working together for health. World Health Organization.

[26] Aghaarabi, E., Aminravan, F., Sadiq, R., Hoorfar, M., Rodriguez, M. J., \& Najjaran, H. (2014). Comparative study of fuzzy evidential reasoning and fuzzy rule-based approaches: an illustration for water quality assessment in distribution networks. Stoch Environ. Res and Risk Assess., 28(3), 655679. 
[27] Dandadzi, P., Hoko, Z., \& Nhiwatiwa, T. (2020). Investigating the occurrence of algae in the drinking water supply system of Harare, Zimbabwe. Journal of Water, Sanitation and Hygiene for Development.

[28] Sorlini, S., Palazzini, D., Sieliechi, J. M., \& Ngassoum, M. B. (2013). Assessment of physicalchemical drinking water quality in the Logone Valley (Chad-Cameroon). Sustainability, 5(7), 30603076 .

[29] Mondal, N. C., Singh,V. S., Saxena, V.K.,\&Prasad, R. K. (2008). Improvement of groundwater quality due to fresh wáter ingress in Potharlanka Island, Krishna delta, India. Environmental Geology, 55(3), 595-603

[30] Rusydi, A. F. (2018, February). Correlation between conductivity and total dissolved solid in various type of water: A review. In IOP Conference Series: Earth and Environmental Science (Vol. 118, No. 1, p. 012019). IOP Publishing.

[31] Rawat, R., \& Siddiqui, A. R. (2019). Assessment of Physiochemical Characteristics of Drinking Water Quality in Allahabad Metropolitan City, India. The Oriental Anthropologist, 19(1), 121-135.

[32] Jameel, P. (1989). The use of ferrous chloride to control dissolved sulfides in interceptor sewers. Journal (Water Pollution Control Federation), 230-236.

[33] Hansen, B., Thorling, L., Schullehner, J., Termansen, M., \& Dalgaard, T. (2017). Groundwater nitrate response to sustainable nitrogen management. Scientific Reports, 7(1), 1-12.

[34] Nezhad, A. B., Emamjomeh, M. M., Farzadkia, M., Jafari, A. J., Sayadi, M., \& Talab, A. H. D. (2017). Nitrite and nitrate concentrations in the drinking groundwater of Shiraz City, South-central Iran by statistical models. Iranian journal of public health, 46(9), 1275.

[35] Crabtree, Koby T; Eubanks, John; Hine, Ruth L., Editor Nitrate and nitrite variation in ground water (Technical bulletin (Wisconsin Department of Natural Resources), No. 58) Madison, Wisconsin: Wisconsin Department of Natural Resources, 1972.

[36] Sojobi, A.O. Evaluation of groundwater quality in a rural community in North Central of Nigeria. Environ Monit Assess 188, 192 (2016). https://doi.org/10.1007/s10661-016-5149-y

[37] Khatri, N., \& Tyagi, S. (2015). Influences of natural and anthropogenic factors on surface and groundwater quality in rural and urban areas. Frontiers in Life Science, 8(1), 23-39.

[38] Igbinosa, I. H., \& Uwidia, I. E. (2018). Effect of abattoir effluents on the physicochemical properties of a receiving watershed in an urban community. Ife Journal of Science, 20(2), 219-228.

[39] Fawell, J., Bailey, K., Chilton, J., Dahi, E., \& Magara, Y. (2006). Fluoride in drinking-water. IWA publishing.

[40] Kannel, P. R., Lee, S., Lee, Y. S., Kanel, S. R., \& Khan, S. P. (2007). Application of water quality indices and dissolved oxygen as indicators for river water classification and urban impact assessment. Environmental monitoring and assessment, 132(1-3), 93-110. 
[41] Laluraj, C. M., Gopinath, G., \& Dineshkumar, P. K. (2005). Groundwater chemistry of shallow aquifers in the coastal zones of Cochin, India. Applied Ecology and Environmental Research, 3(1), 133-139

[42] Nawab, B., Esser, K. B., \& Baig, S. A. (2017). Impact of pit latrines on drinking water contaminations in Khyber Pakhtunkhwa, Pakistan. Environmental Forensics, 18(4), 296-306. 
Figures

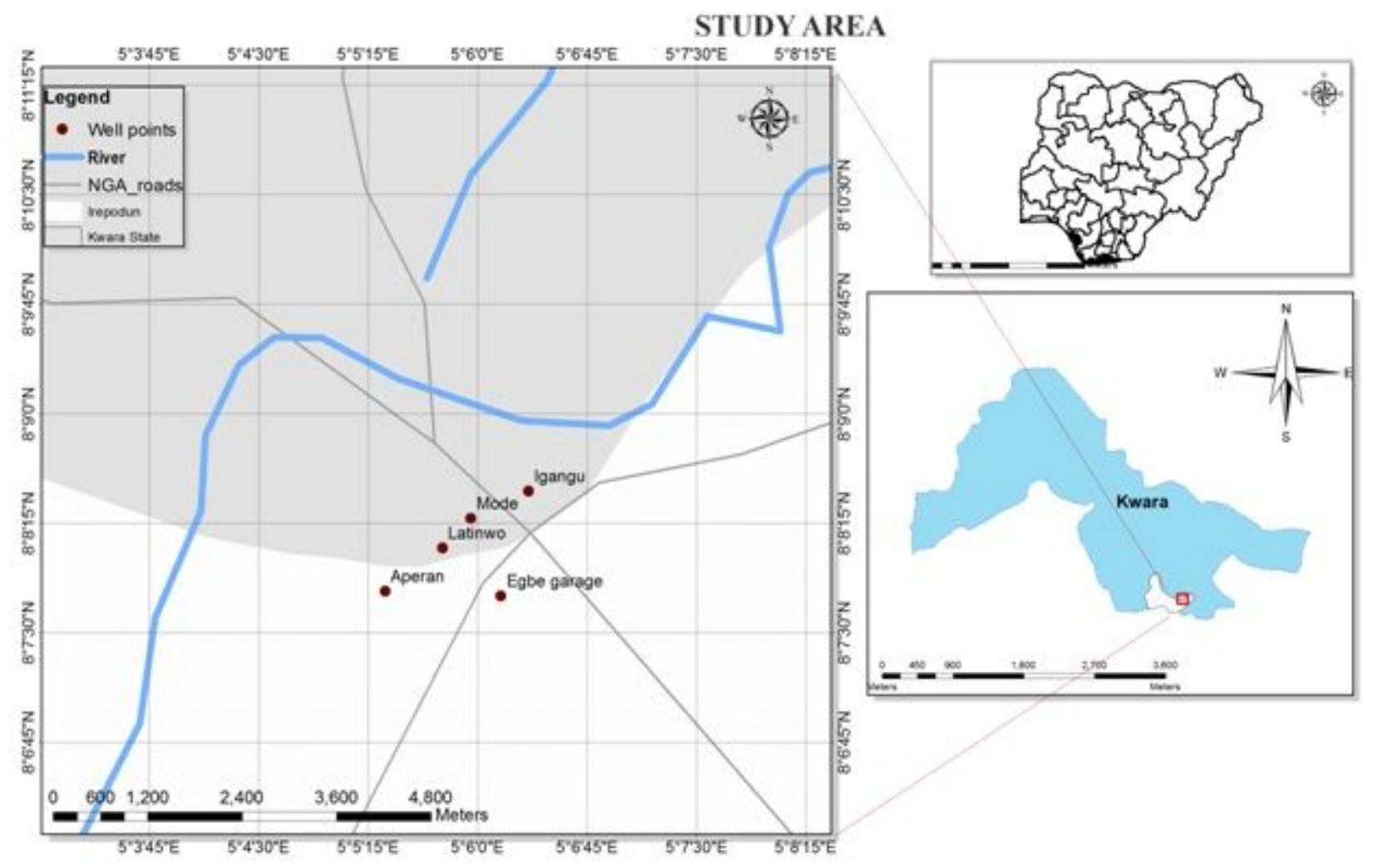

Figure 1

Geographic location of the study area in Omuaran in Kwara State.

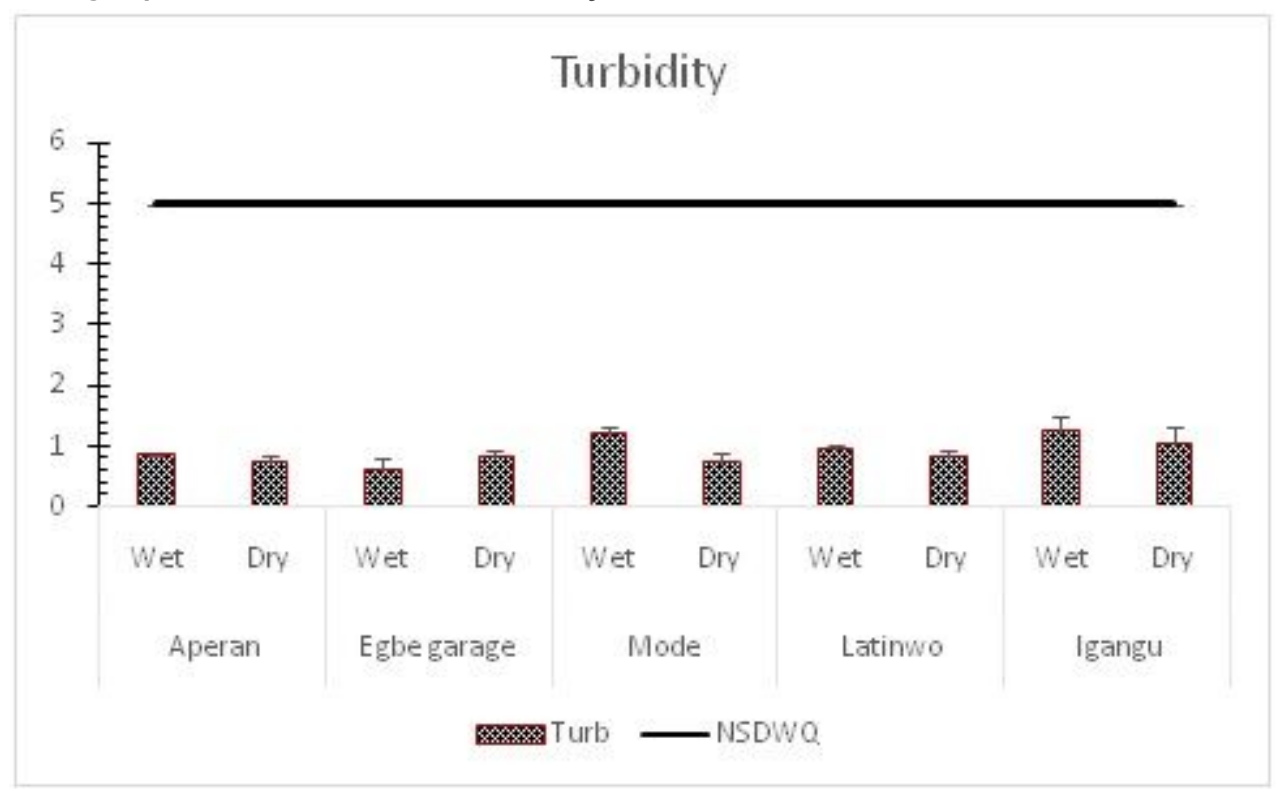

Figure 2

Turbidity values for each location as compared to NSDWQ values. 


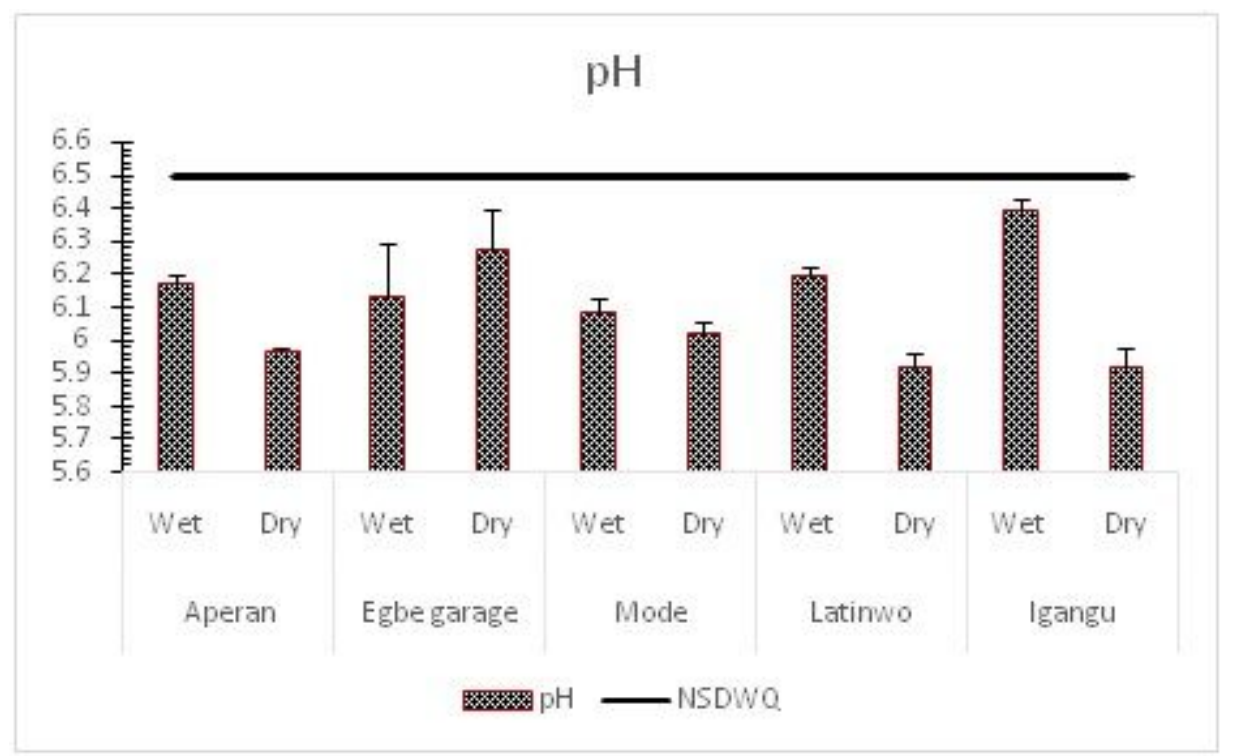

Figure 3

$\mathrm{pH}$ values for each location as compared to NSDWQ values.

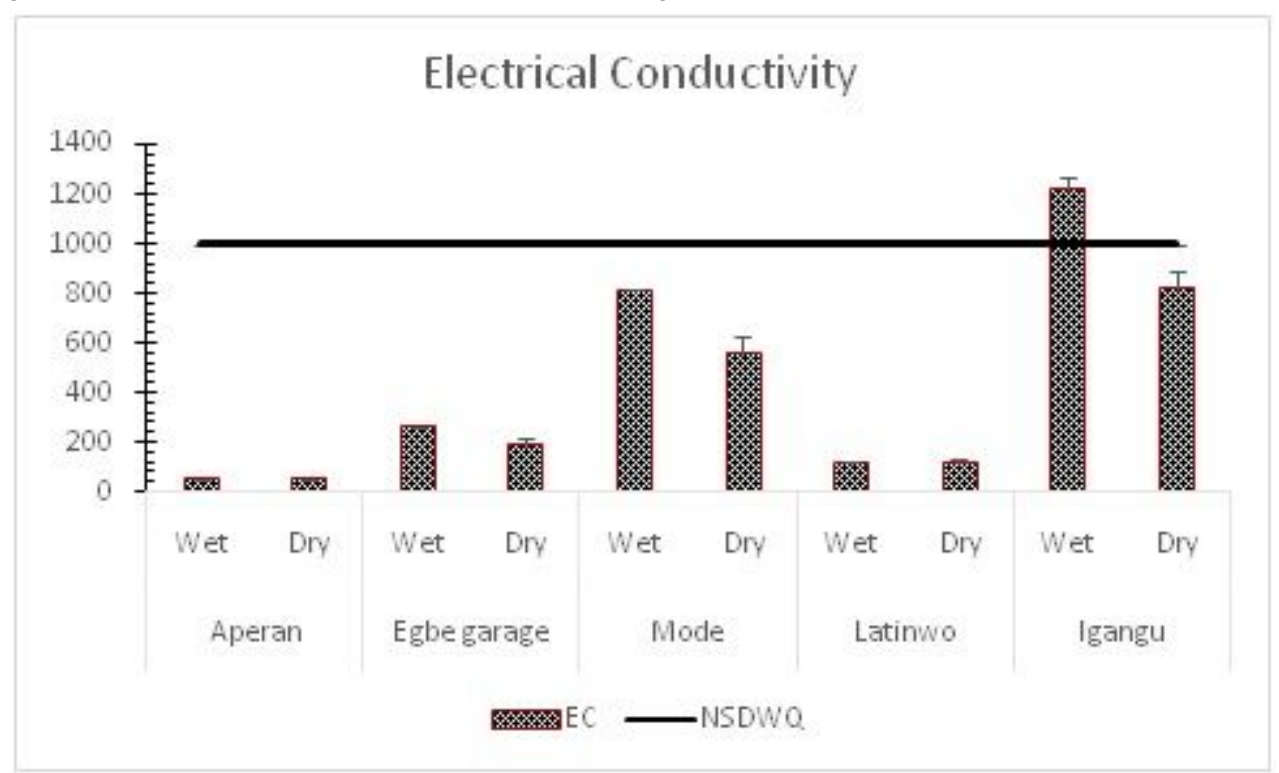

Figure 4

EC values for each location as compared to NSDWQ values 


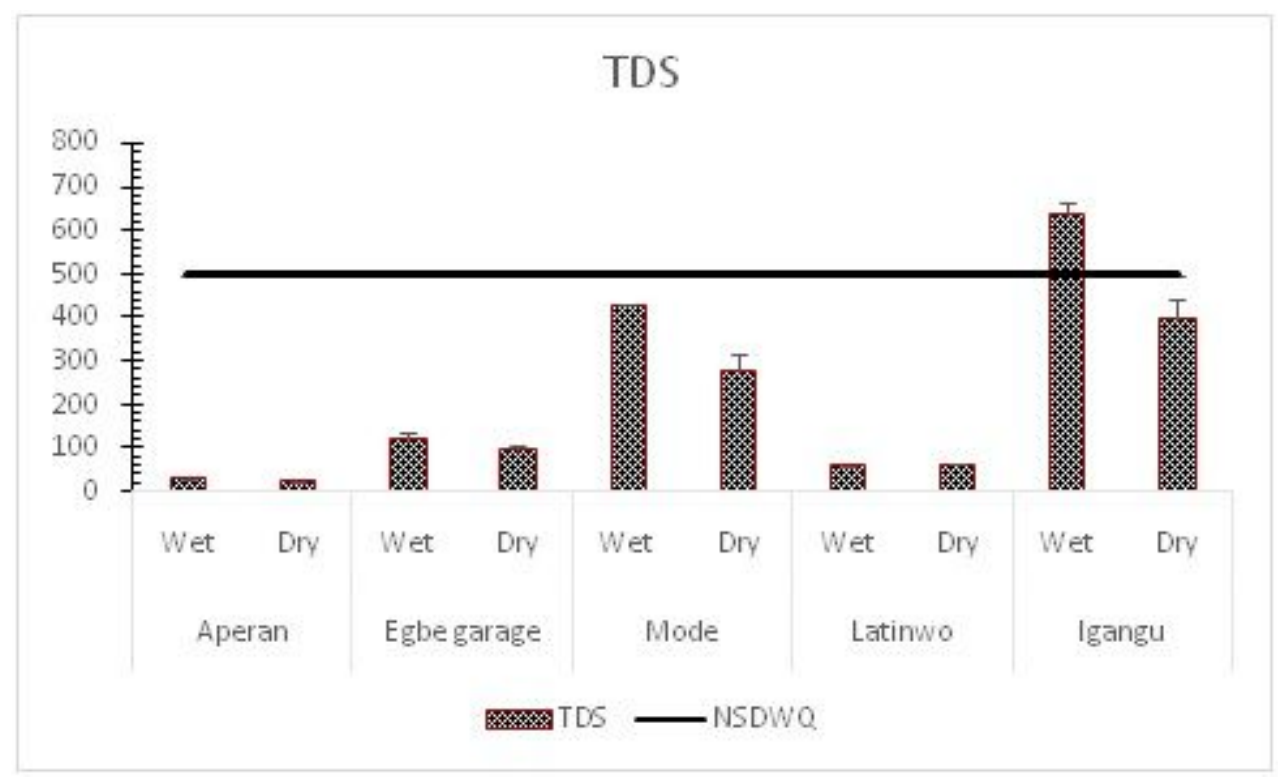

Figure 5

TDS values for each location as compared to NSDWQ values.

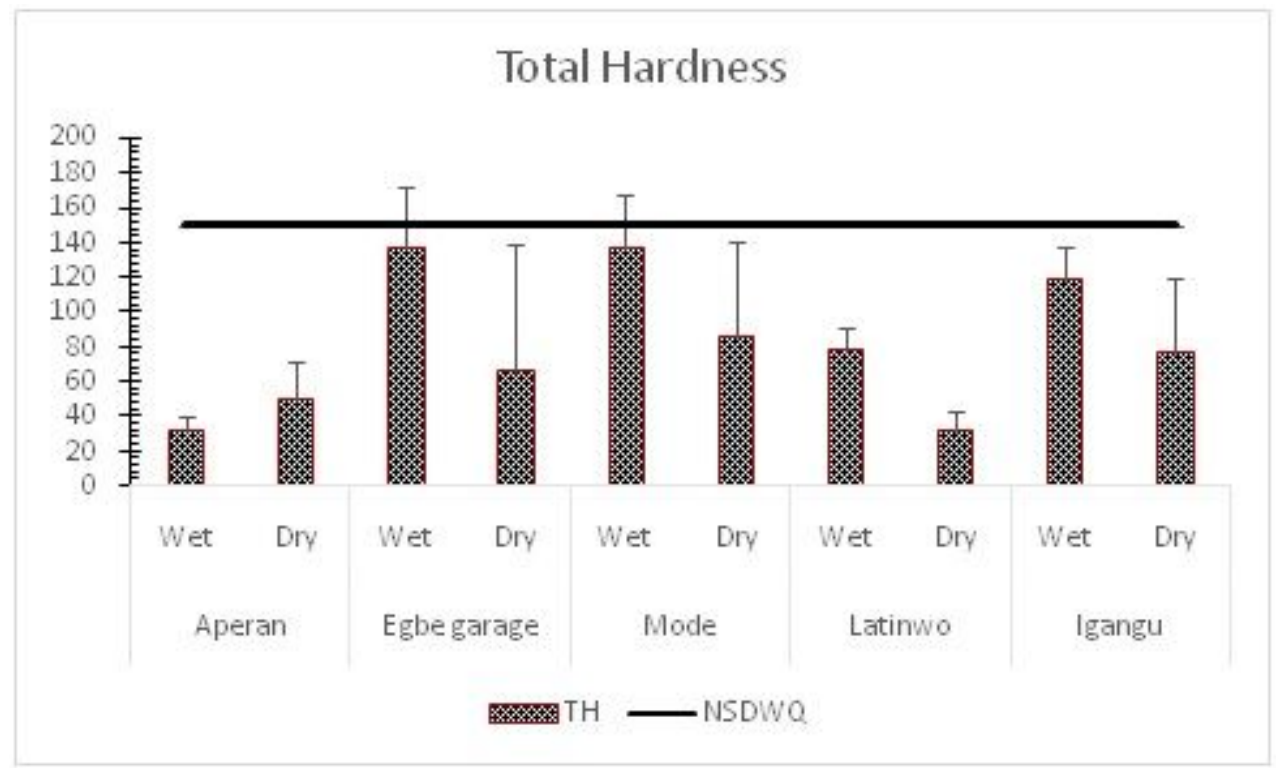

Figure 6

Total Hardness values for each location as compared to NSDWQ values. 


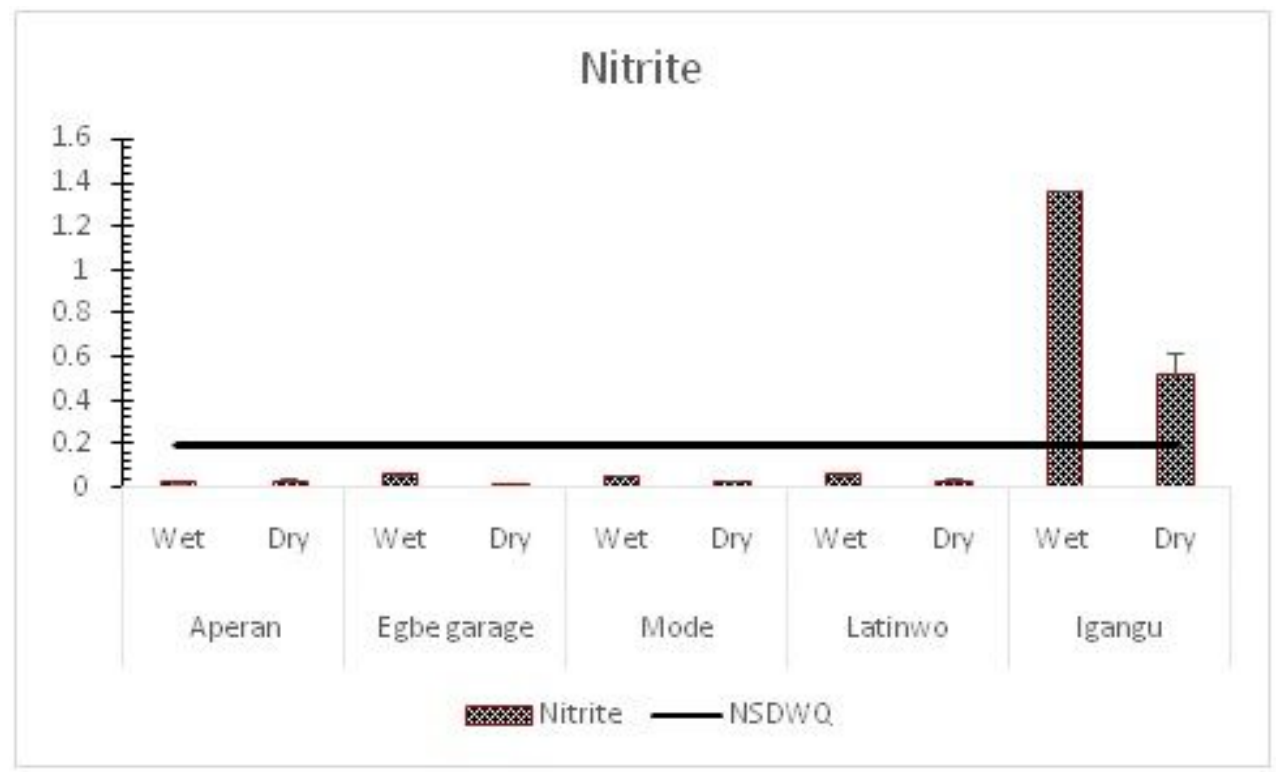

\section{Figure 7}

Nitrite values for each location as compared to NSDWQ values.

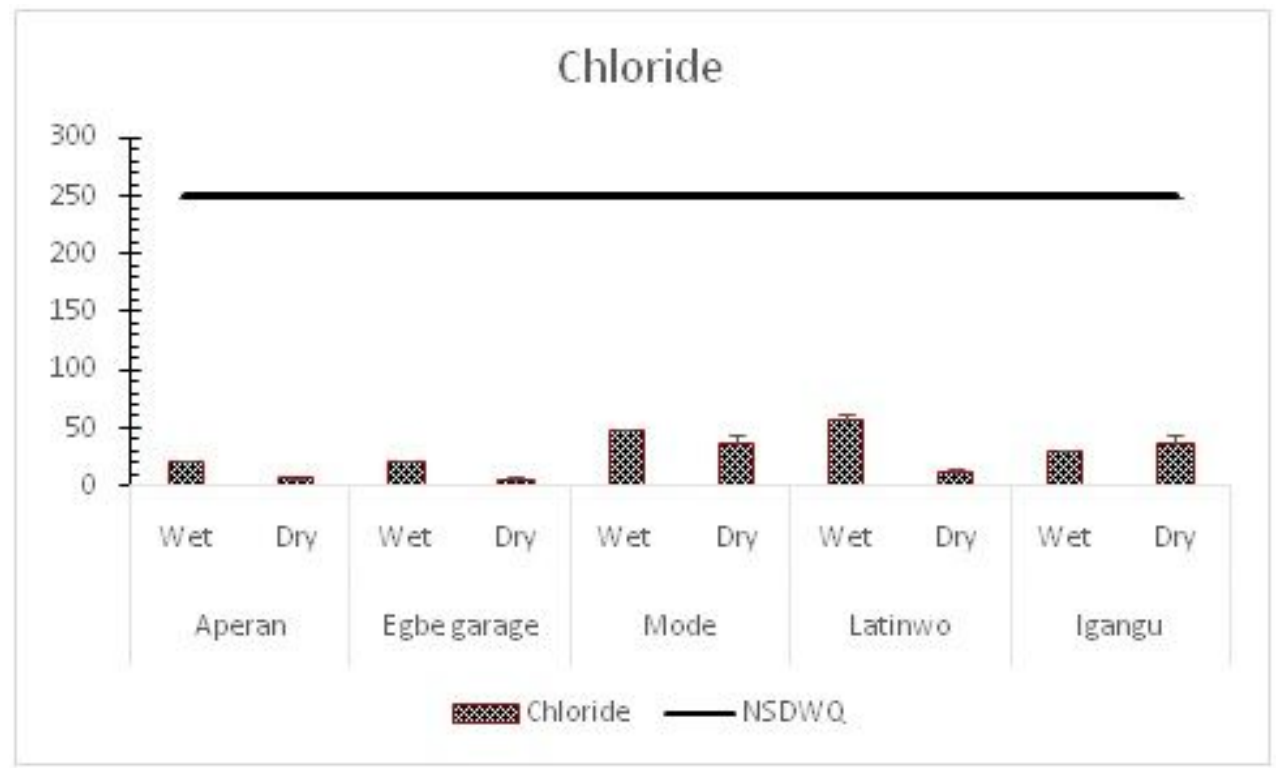

Figure 8

Chloride values for each location as compared to NSDWQ values. 


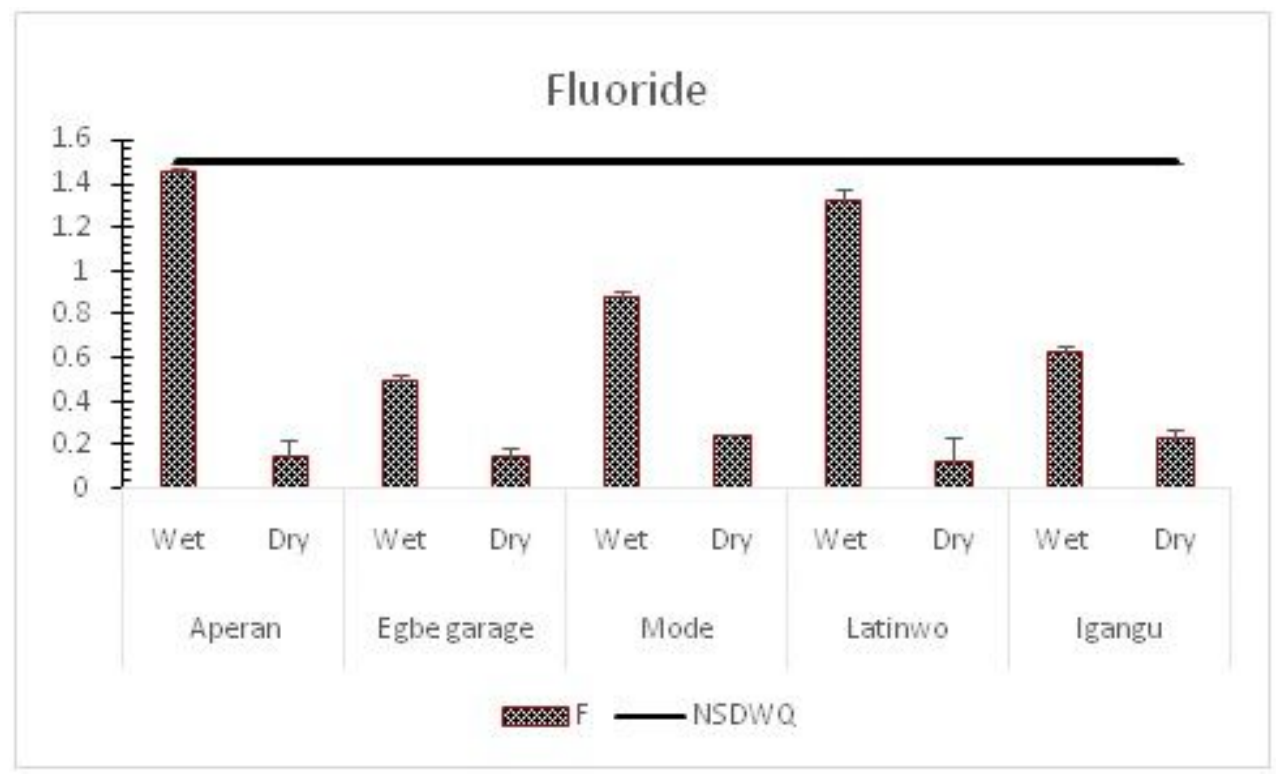

Figure 9

Fluoride values for each location as compared to NSDWQ values.

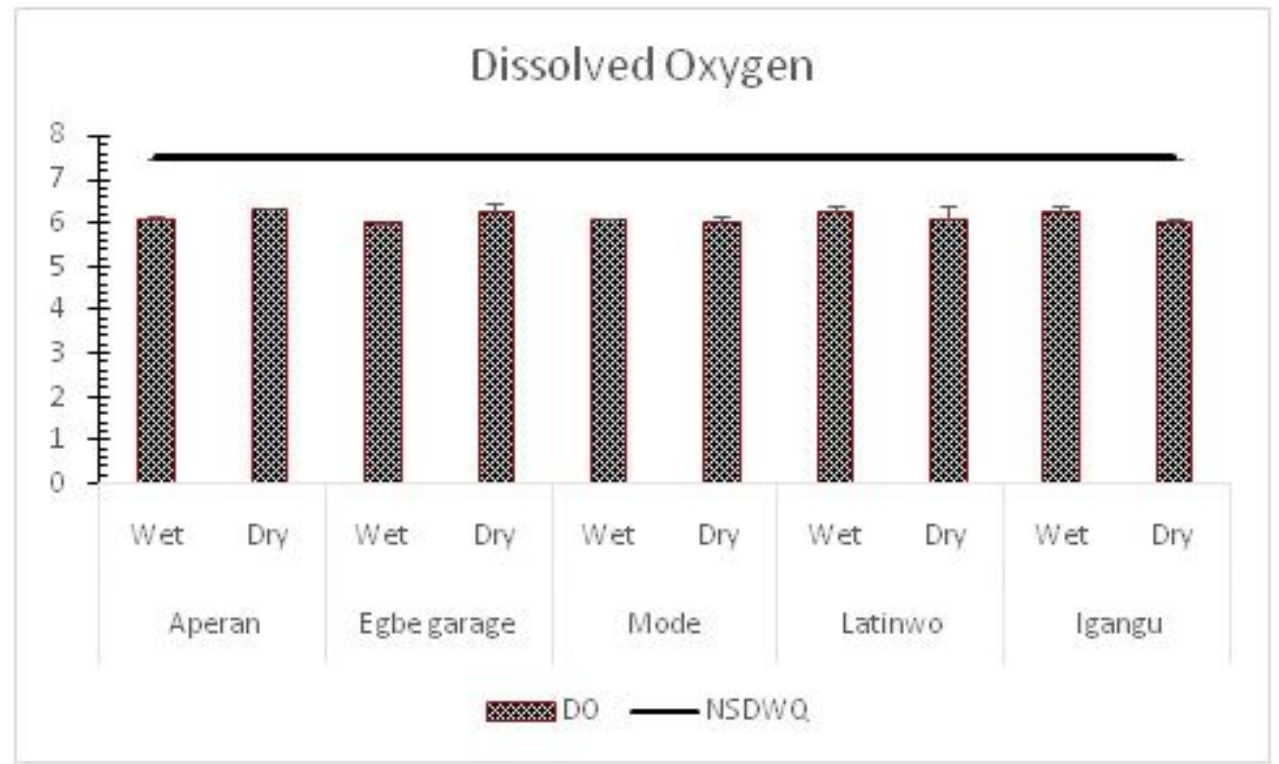

Figure 10

Dissolved Oxygen values for each location as compared to NSDWQ values. 


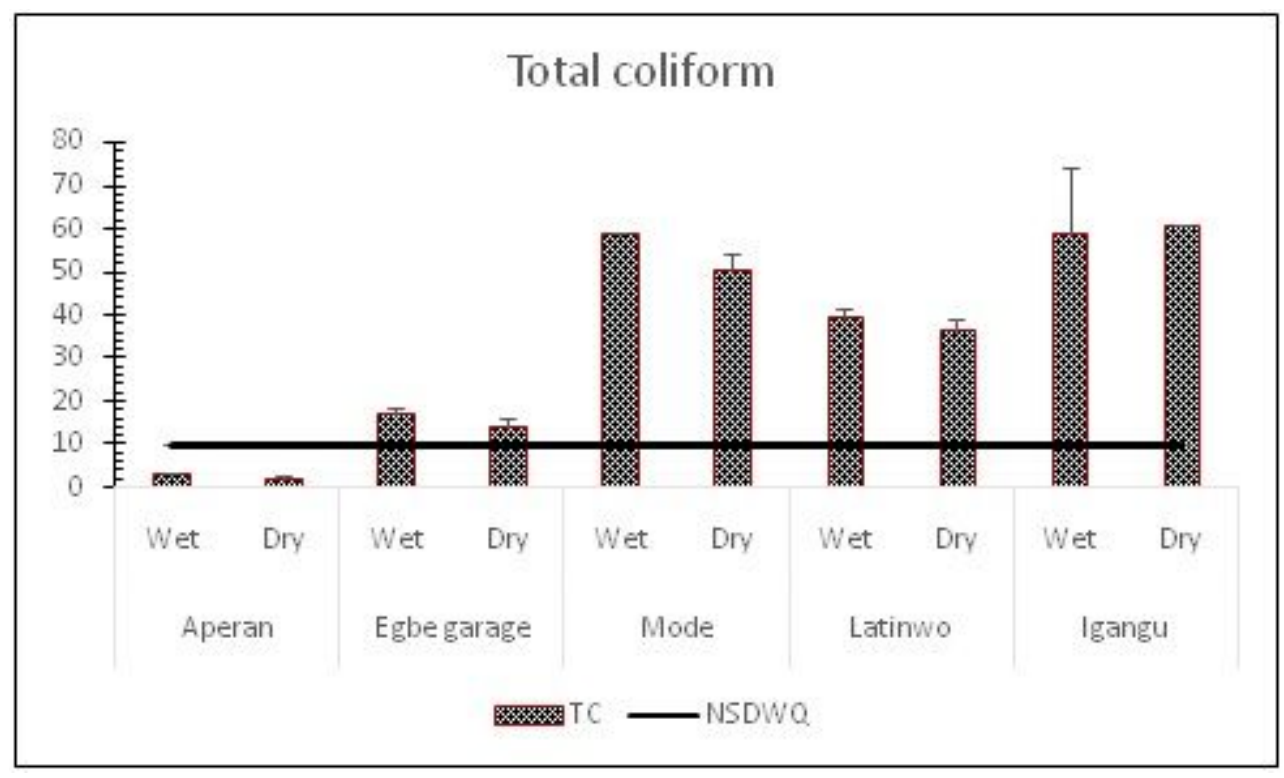

\section{Figure 11}

Total Coliform values for each location as compared to NSDWQ values.

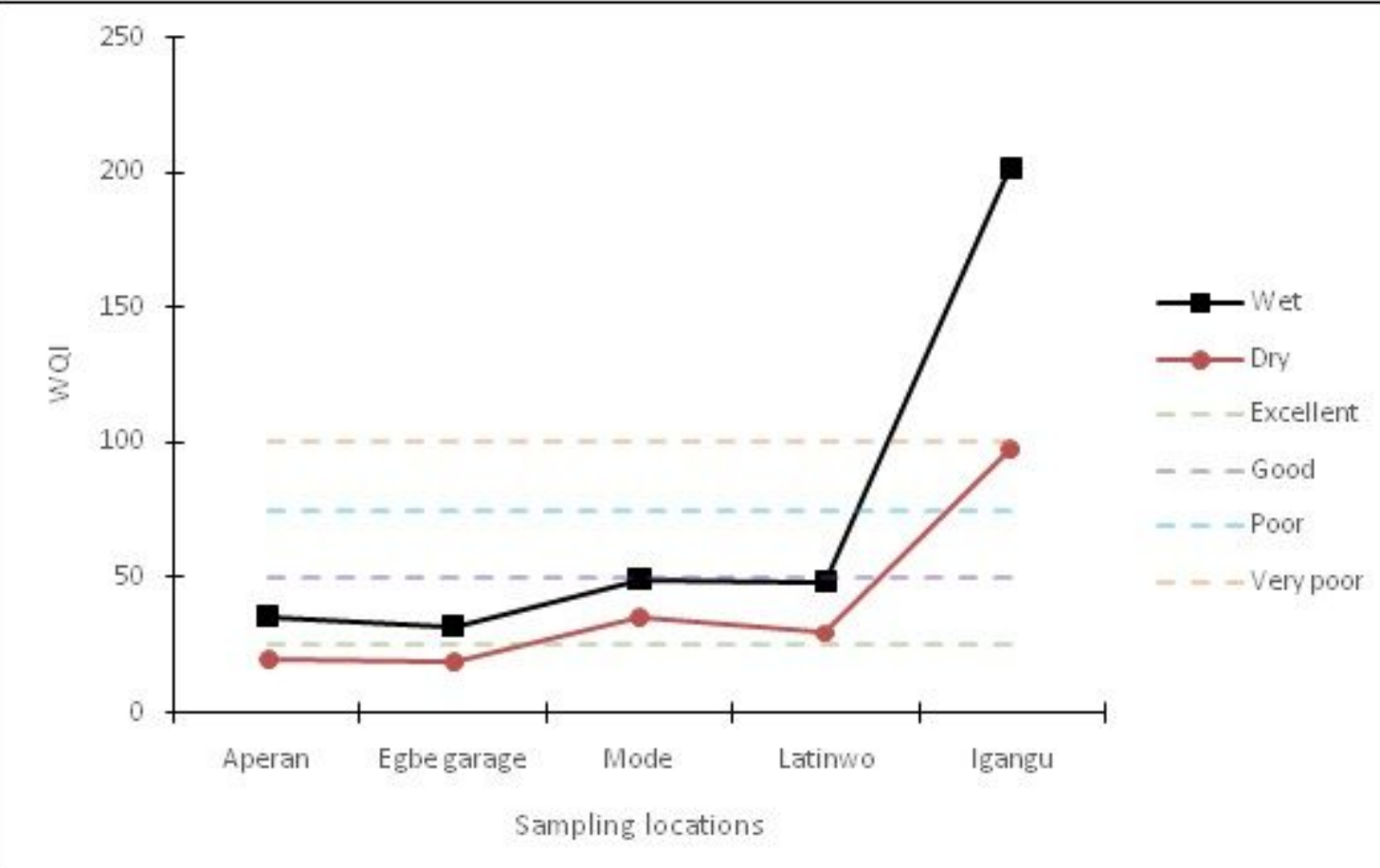

Figure 12

Weighted average water quality index for selected study area 